\title{
Az emigráns magyarok életkörülményei és -stratégiái a legfontosabb európai migrációs célországokban
}

\section{Living conditions and strategies of Hungarian emigrants in the most important European target countries}

\author{
SISKÁNÉ SZILASI BEÁTA, HALÁSZ LEVENTE, \\ VADNAI PÉTER
}

SISKÁNÉ SZILASI Beáta: tanszékvezető egyetemi docens, Miskolci Egyetem, Műszaki Földtudományi Kar, Földrajz-Geoinformatika Intézet; 3515 Miskolc-Egyetemváros; ecobea@uni-miskolc.hu

HALÁSZ Levente: tudományos munkatárs, Miskolci Egyetem, Műszaki Földtudományi Kar, Földrajz-Geoinformatika Intézet; 3515 Miskolc-Egyetemváros; halaszlevente@hotmail.com VADNAI Péter: tanszéki mérnök, Miskolci Egyetem, Műszaki Földtudományi Kar, Földrajz-Geoinformatika Intézet; 3515 Miskolc-Egyetemváros; ecovape@uni-miskolc.hu

KULCSSZAVAK: emigráció; életstratégiák; hazautalás; célországok; szubjektív jóllét

ABSZTRAKT: A magyarok emigrációja - 1989 óta nem tapasztalt dinamikus növekedésének, univerzális életstratégiává válásának köszönhetően - napjainkban a multi- és interdiszciplináris társadalomtudományi kutatások homlokterébe került. A Legújabb trendek a magyarországi kivándorlásban címü kutatás - amelyet 2013 és 2017 között folytattunk - empirikus eredményei több szemszögből vizsgálják a magyar társadalmat és gazdaságot sújtó kivándorlás jellegzetességeit. A kutatás egyrészt a magyarok migrációs hajlandóságára, a kiköltözéssel kapcsolatos attitüdökre fókuszál, másrészt a már kivándorolt magyar állampolgárok külföldi élettapasztalatait, a kiköltözésre ösztönzés okait, a külföldi lét előnyeit és hátrányait részletezi. A tanulmány bemutatja a kivándorlás hullámzó trendjeit, a célországok integrációs jellegzetességeit, a külföldi életvitel eltérő stratégiáit, az emigráns magyarok szubjektív jóllétének különbözőségeit, végül a migrációra és a visszatérésre (remigráció) ösztönző tényezőket.

Beáta SISKÁNÉ SZILASI: associate professor, head of department, Institute of Geography and Geoinformatics, Faculty of Earth Science and Engineering, University of Miskolc; H-3515 Miskolc, Hungary; ecobea@uni-miskolc.hu

Levente HALÁSZ: research fellow, Institute of Geography and Geoinformatics, Faculty of Earth Science and Engineering, University of Miskolc; H-3515 Miskolc, Hungary; halaszlevente@hotmail.com Péter VADNAI: PhD student, Institute of Geography and Geoinformatics, Faculty of Earth Science and Engineering, University of Miskolc; H-3515 Miskolc, Hungary; ecovape@uni-miskolc.hu

KEYWORDS: emigration; life strategies; remittances; target countries; subjective well-being

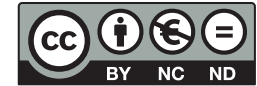


ABSTRACT: Emigration has become a universal life strategy independent of sex, age, social strata, education level, place of birth, socialization specificities or other cultural features. Hungarians emigration was lagging behind neighbouring post-socialist countries' which produced an extraordinary outflow since 2000. However, from 2010, EU labour market liberalization and the great financial crisis burdening thousands of Hungarian families with debt led to the intensification of Hungarian emigration. The principal target countries are Germany, the United Kingdom and Austria where more than 300,000 Hungarians are living in diaspora. Besides, labor mobility also focuses on other economically powerful states like Sweden, Finland, Switzerland, the Netherlands, Belgium and, furthermore, to transitional countries such as Poland and Slovakia. According to official and semi-official estimates approximately 350,000-600,000 Hungarians live abroad of whom 80-85\% are employed. A minority of them are studying at foreign higher education institutions or living with emigrant relatives. The dynamics of emigration was accelerated between 2010 and 2014, though for the last two years the process has been showing signs of stagnation or deceleration. It is hard to predict future migration scenarios as many factors (e.g. macroeconomic situation, bureaucracy, social welfare and health system, quality of education, politics) influence individual and collective decisions. Nowadays migratory lifestyle (permanent, temporary or recurring) is also became an alternative strategy supported by complex, multilateral interpersonal networks and the social environment. A high level of emigration (especially from the peripheral rural areas causing brain drain and social residualization) jeopardizes the Hungarian society's social welfare and health systems, education and state administration and, therefore, requires political interventions. While the increasing amounts of remittances comprise $3 \%$ of the Hungarian GDP, this does not lead to direct economic development as most of the families use this income to repay debts and increase their life standard. Even more, two third of emigrants do not plan remigration and they even persuade other family members to leave the country. One third of emigrants perceive migration as an episode of adult life offering financial empowerment opportunities. They return back to Hungary with specific family, entrepreneurial, career or patriotic incentives. Numerous factors stimulate migration: macroeconomic instability, low wages, financial recession, quality of education, political differences, disappointment, poverty, unemployment, hopelessness or uncertainty. On the other hand, target countries are popular because of 4-6 times higher salaries, career opportunities, potential savings, better life conditions, cultural diversity, inclusive societies, advantages of socialization in a multicultural social environment, quality education, intact nature and a reliable future.

\section{Bevezetés}

A nemzetközi migráció az emberiség számára fő kihívássá, lehetőséggé és megoldásért kiáltó problémává vált. A végérvényes vagy ideiglenes, munkavállalási vagy tanulási célú migráció egyre inkább általános életstratégiává válik. A mobilitási kapcsolatrendszerek szélesedése, a közlekedés bővülő lehetőségei, a kommunikáció fejlődése, az új technológiák megjelenése egyszerübbé és olcsóbbá teszik az elvándorlást. Magyarországon is felgyorsult az elvándorlás, amelynek intenzitását bizonyítja, hogy az elmúlt évtizedben évente egy nagyjából Vác méretű város lakossága (33000 fó) hagyja el Magyarországot. Jelen tanulmány a magyarok emigrációjára fókuszál és három adatgyüjtésre támaszkodik:

- Magyarország megyei jogú városaiban 9876 főt kérdeztünk meg (papíralapú kérdőívekkel), migrációs attitüdjükre, hajlandóságukra koncentrálva. 
- Ugyanezt a kérdőívet kissé átalakítva használtuk a legfontosabb célországokban (Németország, Nagy-Britannia, Ausztria, Spanyolország, Olaszország, Lengyelország, Benelux államok, Svédország, Svájc) élő magyarok életkörülményeinek és életstratégiáinak megismerésére. A felmérésben 245 fö vett részt.

- A kutatás elmélyítése érdekében 2016 és 2017 folyamán 56 félig strukturált mélyinterjút készítettünk.

A második, online adatgyüjtésben az alábbi kérdésekre fókuszáltunk: a külföldi munkavállalásra ösztönző/kényszerítő tényezők, a megérkezéskor, a munkába állás kezdetekor felmerülő nehézségek, a külföldi magyarok közötti kapcsolati háló összetettsége és minősége, a fizetéssel, az előrejutás lehetőségeivel való megelégedettség, a hazaköltözés esélye, a hazalátogatás sűrűsége, az otthon maradt családtagok kiköltözésének valószínűsége, a hazaküldött pénzbeli támogatások, a migrációs lánc jellege, eltérő életstratégiák. Emellett több szociodemográfiai alapinformációra is rákérdeztünk: állampolgárság, jelenlegi és a kiköltözést megelőző magyarországi lakóhely, kor, nem, legmagasabb iskolai végzettség, külföldi munkahely megléte, beosztás, idegen nyelvek ismerete. Alternatív, szelektív és skálatípusú kérdéseket alkalmaztunk. A felmérésben részt vevő emigráns magyarokat mind célzottan, mind a hólabdaszabály segítségével térképeztük fel (ezáltal a kapcsolati hálóról is értékelhető képet kaptunk), ügyelve arra, hogy koruk, nemük, legmagasabb iskolai végzettségük feleljen meg a különböző migrációspecifikus statisztikák szociális és demográfiai jellemzőinek (Blaskó, Fazekas 2016; European Commission 2014; Fazekas, Varga 2015; Kolosi, Tóth 2014, 2016; KSH 2014; Lakatos 2015). Azokat a célországokat vontuk be a vizsgálatba, ahol népesebb magyar diaszpórák találhatók. A terepmunkát kismintás (15 fö) papíralapú próbakérdezéssel indítottuk 2016 nyarán, ezt követően készült el a végleges, validált online kérdőív. A kérdőívezés 2016 szeptemberétől 2017 áprilisáig tartott. Az esetleges hibákat pótlekérdezéssel korrigáltuk. A felvételezés során keletkező - a mintamegoszlásból származó - különbözőségeket súlyozással javítottuk, nemre, korcsoportra és iskolai végzettségre vonatkozóan. A kutatás nem reprezentatív.

A félig strukturált interjúk esetében szintén a fontosabb migrációs célországokra koncentráltunk, részben helyben készítettünk interjúkat (London, Walton-on-Thames, Bécs, Innsbruck, Worms, Freiburg, Dortmund), részben az időközben hazaköltözött (tehát remigráns) magyarok tapasztalatai iránt érdeklődtünk. Az interjúalanyokat hólabdaszabály segítségével értük el, így készültek az egyéni interjúk (mind a migrációra vonatkozó rövidebb, mind a hosszú és kötetlen életútinterjúk). Ezen kívül minden célországban egy-egy fókuszcsoportos interjú keretében érdeklődtünk az emigrációs életstratégiákról, életvitelről, tervekről. Célzottan is készítettünk interjúkat a külföldi magyarok munkába állását segítő szervezetek vezetőivel, képviselőivel. 


\section{A magyarok kivándorlásának időbeli hullámzása}

Egy nagyobb térségben vagy országban élők migrációjának alakulását számos szociális, politikai, gazdasági és ökológiai faktor befolyásolja. Az egykori keleti blokk országait egyrészt az újonnan kialakult munkaerőpiaci, oktatási, egészségügyi és szociális rendszer, az országon belüli gazdasági és társadalmi egyenlőtlenségek, az anyagi depriváció, a várt gazdasági prosperitás elmaradása, másrészt a kelet-európai munkaerő iránti nyugati kereslet növekedése, a migrációs kapcsolatok újonnan kialakult mintázata, a migrációt elfogadó össztársadalmi attitűd, továbbá az általánosan változó, többnyire romló közérzet érinti (Gödri 2015; Kurekova 2011; Lakatos 2015; Piesse 2014).

A magyarok munkavállalási és tanulási célú elvándorlásának időbeli alakulása eltér a kelet- és közép-európai mezotérség társadalmaira jellemző emigrációs folyamatoktól (1. ábra). Hazánkat a 2004-es EU-csatlakozást megelőző évtizedben kismértékü elvándorlás jellemezte, amely a fokozatosan javuló munkaerőpiaci stabilizációnak, a 2000-es évtized első felében a 6\% körüli, kifejezetten alacsony munkanélküliségnek, ezzel párhuzamosan a javuló foglalkoztatásnak és az évi 3-5\%-os GDP-növekedésnek volt köszönhető. A reálbérek jelentősen emelkedtek, ami egyrészt egyszeri béremeléshez volt köthető (2002ben 800000 munkavállaló 50\%-os közalkalmazotti béremelésben részesült), illetve adómentessé tették a minimálbéreket. Az EU-hoz 2004-ben, illetve 2007ben csatlakozott posztszocialista országokból már az integrációt megelőzően megindult az intenzív kivándorlás fóként Európa fejlett gazdaságú térségeibe.

1. ábra: Az általunk megkérdezett magyarok kivándorlásának időpontja (2000-2016) The volume of Hungarian emigration in the sample (2000-2016)

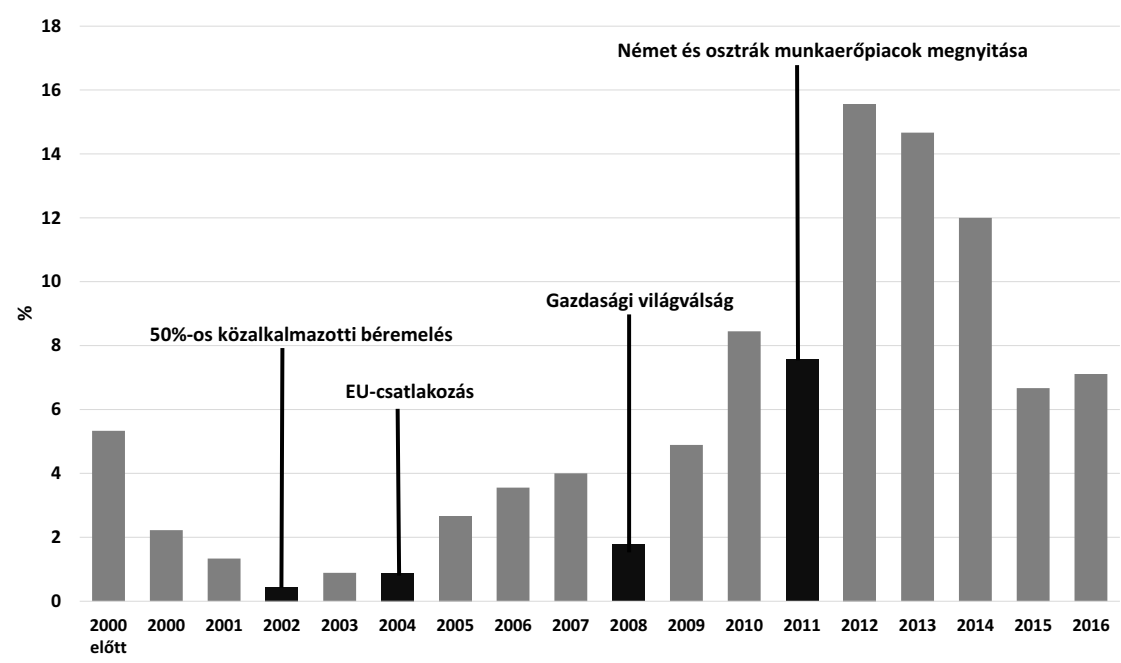

Adatok forrása: online kérdőiv a külföldön élő magyarok körében (n=245). 
A magyar munkaerőpiac ekkor még kevésbé reagált a kínálkozó lehetőségekre. A 2008-ban kirobbant gazdasági és hitelválság - Románia és Bulgária kivételével térségi szinten még átmenetileg fékezte az emigráció ütemét, 2010 után azonban az EU munkaerőpiacának kibővülése szinte sokkhatású volt a kelet-európai országok számára (Hárs 2012, 2016). Kelet-Európában - Magyarországon is - magas szintű, 10\% feletti munkanélküliség és alacsony foglalkoztatottsági szint alakult ki. Ennek következtében nem csak meglódult az elvándorlás üteme Magyarországról, hanem intenzitásában megközelítette a többi új tagországban már korábban kialakult mértéket. (Jelenleg a magyar migráns népesség állományának évi átlagos növekedési aránya közel akkora, mint például Lengyelországban és Szlovákiában volt 2004-ben, azonban elmarad az erőteljes baltikumi, romániai és bolgár exodustól.) Massey és szerzőtársai (1993) nyomán úgy véljük, hogy a későn indult migráció okainak együttese gyorsította fel az elvándorlás bővülését Magyarországon. A 2011-től tapasztalható - a demográfiai helyzetet súlyosbító erőteljes növekedést a nemzetközi és hazai kutatások (pl. Blaskó, Fazekas 2016; Kolosi, Tóth 2016; KSH 2014, illetve saját kérdőíves felmérésünk eredményei) szerint hosszan elnyúló stagnálás, lassú visszaesés követ(het)i. Ezt támasztja alá a magas fokú kivándorlási hajlandósággal rendelkező magyarok tudatosan rövid vagy középtávra tervezett emigrációja, tehát a tanulási célú vagy az anyagi megerősödés céljából történő külföldi munkavállalás mint az elvándorlás fő motivációja. A vizsgálatba bevont már külföldön élő magyarok 77\%-a nem tervezi a hazaköltözést (az emigráns idősödésével a remigrációs hajlandóság mértéke csökken), 22\%-a viszont tudatosan bizonyos időre hagyta csak el Magyarországot. Közülük 29\% egy évre költözött külföldre, 44\%-uk 2-4 évre, 5 évre 21\%, míg 10 évnél hosszabb távra 5\%. A visszavándorlást is szelektivitás jellemzi, a Magyarországon hagyott család, a külföldi beilleszkedés nehézségei, a túlképzettség (vagy az elégtelen kvalifikáció) a hazatérést is motiválhatja (Blaskó, Fazekas 2016; Blaskó, Gödri 2014; Rohr 2012; Szeitl 2015). Az is igaz, hogy a szakmájától eltérő (alacsonyabb presztízsü) munkát vállalók visszatérése az esetek többségében is csak átmeneti, ha a hazai munkaerőpiacon újra sikertelenné válnak (például akkor, ha a külföldön elért szinttől jelentősen elmarad az itthon elérhető jövedelem, vagy a külföldi tartózkodást bünteti a hazai munkaerőpiac) (Horváth 2016; Lados, Hegedüs 2016; Martin, Radu 2012).

\section{A magyar kivándorlás területisége}

A magyarok számára leginkább kedvelt migrációs célországok sorrendje keveset változott az elmúlt két-három évtized folyamán (Blaskó, Ligeti, Sik 2014; Gödri 2015; Hárs 2008, 2016; Kurekova 2011; Martin, Radu 2012). Németország az Egyesült Királysággal holtversenyben maradtak a legvonzóbb államok (2. ábra), a harmadik helyen Ausztria áll, majd ezeket az észak-európai jóléti országok, a 
2. ábra: Az 1989 óta emigrált Magyarországon született magyar állampolgárok száma (fó) Number of Hungarian citizens migrated to other European countries since 1989

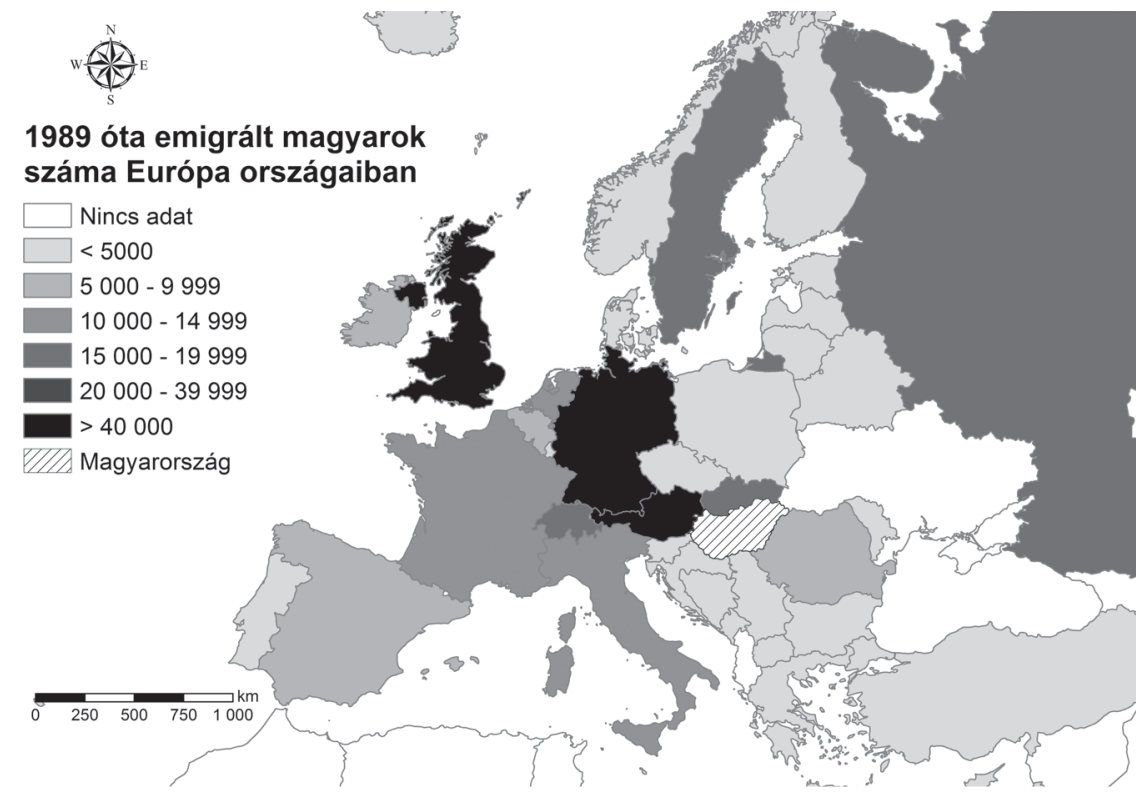

Adatok forrása: UN (2017).

Benelux államok, Svájc, Franciaország, Olaszország, Spanyolország, Oroszország, Lengyelország, Szlovákia követi. Nagy általánosítással elmondható, hogy a magasan képzettek inkább az Egyesült Királyságot és Észak-Európát, a szakmunkások Németországot, Svájcot, a Benelux államokat és a mediterrán országokat választják. Az Ausztriában és a posztszocialista térségben letelepedők összetétele vegyesebb: innen a leggyakoribb a hazaköltözés, illetve a tudatosan rövid idejü migrációt tervezők legnagyobb hányada is ezt a térséget választja.

Saját kutatási eredményeink egybeesnek a fentebb említett célországválasztási preferenciákkal. Mind a Magyarországon élő határozott emigrációs hajlandósággal rendelkező ( $\mathrm{n}=9876)$, mind a már külföldön tanuló/dolgozó magyarok ( $\mathrm{n}=245)$ számára Németország, Nagy-Britannia és Ausztria jelentik a fö migrációs célpontot. Ezt követően a dél-európai országokat (Olaszország, Spanyolország), illetve a skandináv térségből kiemelkedően Svédországot jelölték legtöbben jövőbeli letelepedésük helyszínéül, illetve nagy számban már évek óta ezen országokat lakják. Az Elbától keletre eső államok közül Lengyelország emelhető ki, amely az általunk megkérdezett magyarok számára kedvező megélhetőségi lehetőségeket, magasabb fizetést biztosító célország, elsősorban munkavállalási célú emigránsok számára.

A magyarok szemszögéből legvonzóbb három célország közül Németország évtizedek óta - hullámzó intenzitással - a magyar munkavállalók fő célországa. A német munkaerőpiac 2011-es megnyitása óta folyamatosan növekszik a rövi- 
debb-hosszabb időtávra ideérkező magyarok száma, akik elsősorban Bajorországban, Baden-Württembergben, Hessenben, valamint a nagyvárosokban (Berlin, Hamburg, Ruhr-vidéki konurbáció) telepednek le. 2010-ben 21 000, 2012-ben 40 000, 2014-ben 78 000, míg 2016-ban 100800 magyar állampolgár dolgozott Németországban, igaz, hogy nagyjából a magyar migránsok fele egy évnél rövidebb ideig. A munkavállalókon kívül tanulási, családi okok miatt még nagyobb számban élnek itt magyarok (2013 végén összesen 135614 fö), 50\%-uk 4 évnél rövidebb ideje vándorolt be, tehát nem képezi integrált részét a német társadalomnak. Az észak-európai államok után itt keresnek legtöbbet a munkavállalók, közel 700000 forintnak megfelelő eurót, emellett jelentős szociális és jóléti juttatások igénylésére is lehetőségük nyílik. Példaként említendő a két gyermek után járó havi 400 eurós családi pótlék, amelyet akkor is megkap a szülő, ha a gyermekei Magyarországon élnek (Heti Világgazdaság 2014). A magyarok Németországba való bevándorlásának dinamizmusa 2016-tól mérséklődött, ellentétben más kelet-európai országokból növekvő bevándorlással. 2016-ban 414000 lengyel, 294000 román, 283000 olasz, 165000 horvát, 115000 bolgár, 29000 szlovák, 51000 cseh dolgozott Németországban (Bundesagentur für Arbeit 2017; Destatis 2017).

Az Egyesült Királyság a 2004-es EU integrációt követően fontos migrációs célországgá vált a magyarok számára. A kivándorlás volumene folyamatosan növekedett, 2010 óta erőteljes dinamizálódás tapasztalható. Míg 2012-ben 50000 munkavállaló élt Nagy-Britanniában, ma számuk 96000 fö, fele Nagy-Londonban él (Vargas-Silva 2017). A népszerü toposszal (pl. a szociális ellátórendszeren élősködő bevándorlók) ellentétben az ország valódi vonzerejét nem a juttatások, hanem a munkalehetőségek és a magasabb fizetés jelenti, ugyanis a szigetországban a minimálbér 445000 forintnak, míg az átlagbér 658000 forintnak felel meg (Eurostat 2017). (Az elkölthető jövedelmi hányad háztartásonkénti mediánértéke Nagy-Britanniában 3,5-szerese a magyar szintnek). Az Egyesült Királyságot nagyobb eséllyel választják a felsőfokú végzettségűek, viszont a túlzott munkaerőkínálat miatt különösen nagyarányú a túlképzettség, így az új EU-országokból érkező felsőfokú végzettséggel rendelkezők több mint fele végez kvalifikálatlan munkát (Hárs 2016). Szintúgy tévhit a nagyszámú magyar munkanélküli, ugyanis a 2004 óta csatlakozott országokból bevándoroltak közül a magyarokat jellemzi a legkisebb munkanélküliség (4,7\%), valamint az ott élő magyarok közül aktívan dolgozók aránya a legmagasabb (82,5\%) (Béni 2016). A magyarok 26,5\%-a dolgozik a vendéglátásban és ugyanennyien a kereskedelemben és egészségügyben, míg más kelet-európai bevándorlók között az ipari szektorban és a szociális szférában elhelyezkedők aránya kiemelkedő (hungarianspectrum.org 2014; Moreh 2014). Az Egyesült Királyságban élő európai bevándorlók közül legnagyobb diaszpórákat a 818000 lengyel, a 227000 román, a 176000 olasz, a 140000 spanyol és az ugyanennyi portugál alkotja (Béni 2016; Vargas-Silva 2017).

Az osztrák munkaerőpiacra vándorló magyarok aránya nőtt meg leginkább látványosan az elmúlt fél évtizedben, ugyanis megduplázódott a magyar mun- 
kavállalók száma. Jelenleg 71000 magyar dolgozik Ausztriában, ezáltal a németek után a magyar alkalmazottak tábora lett a második. A külföldi munkavállalók között a magyarok munkanélkülisége a legalacsonyabb (6,7\%) Ausztriában, és viszonylag alacsony (19\%) a diplomások és magasabb a szakmunkások aránya. Az Eurostat 2017-es adatai szerint nyugati szomszédunknál a minimálbér a magyarországinak négyszerese, 450000 forint, míg az átlagkereset 660000 forint. Bevándorlás szempontjából említést érdemel a 40000 főt kitevő boszniai, a 39000 fös román, a 33000 lengyel és a 24000 szlovák bevándorló. A magyarok számára Ausztria esete különleges. Jelenleg a magyar foglalkoztatottak 2,1\%-a (100 000 fö) ingázik külföldre (ez elmarad a szlovákok 5,8\%-os vagy a románok 2,8\%-os arányától), 87\%-uk az osztrákokhoz jár át dolgozni elsősorban a három nyugat-magyarországi megyéből (Farkas 2015). A földrajzi közelség miatt az Ausztriában letelepedettek közül nagy számban, akár havi rendszerességgel látogatnak haza a munkavállalók, valamint gyakorlatilag minden második-harmadik Ausztriába költöző célja a rövidebb idejű - az anyagi konszolidációt támogató - munkavállalás vagy tanulás, így ebben az esetben relevánsabb mobilitásról, mint migrációról beszélni.

\section{A külföldi munkavállalás mint életstratégia}

A kivándorlást választók között egyre inkább eltűnnek a nem, kor, iskolai végzettség, családi állapot közötti különbségek. A migráció egykori társadalmi jellemzőit (például férfitöbblet, gyermektelenek, egyedülállók, középfokú végzettséggel rendelkezők, kalandvágyók) a 2000-es évek kivándorlási mintázatában még univerzális igazságként fogadták el. Jelenleg azonban gyakorlatilag a társadalmi, jövedelmi, képzettségi hierarchia teljes vertikumából indulnak útnak a magyar állampolgárok (Blaskó, Gödri 2014; Blaskó, Ligeti, Sik 2014; Hárs, Simon 2016). A mi kutatásunk elvándorlóit nőtöbblet jellemezte, iskolai végzettség terén 46\%-ban felsőfokú végzettségüek, 42\%-ban érettségivel, 16\%-ban szakmunkás képesítéssel rendelkeztek. A korcsoportonkénti megoszlást vizsgálva egyre ifjabban válnak mobillá a magyarok, ugyanis a középiskola után minden harmadik-negyedik fiatal felnőtt külföldi felsőfokú oktatási intézménybe jelentkezik. Igaz, hogy a felsőfokú tanulmányok végeztével nagy számban vissza is térnek hazájukba. Az emigránsok többségét 20 és 40 év közötti fiatalok alkotják, viszont a középkorúak között is egyre népszerübb stratégiává válik a külföldi munkavállalás vagy a munkavállalás nélküli családi integrációt célzó „szimpla” kiköltözés (részletesebben lásd a jelen tematikus számban: Siskáné Szilasi, Halász, Gál-Szabó 2017).

A külföldi letelepedés kitaposott ösvényeinek, megismert szokásainak és a fogadó országok nyitott munkaerőpiacainak köszönhetően mára a magyar emigránsok 60\%-a azonnal talál munkát, sőt gyakorta már előre lefixált munká- 
ra érkezik, ötödüknek pedig csekély időre (1-3 hét) van szüksége az ideiglenes vagy állandó elhelyezkedéshez. Csupán a kint élők elhanyagolható része (8\%) küzd a külhoni munkaerőpiaci elhelyezkedéssel. Hangsúlyozandó, hogy a munkavállalók 60\%-a nem végzettségének megfelelő munkát kap, elsősorban azok, akik kevésbé versenyképes felsőfokú végzettséggel és gyenge nyelvtudással rendelkeznek. A karrierépítést segítheti a sokrétü külföldi kapcsolati háló, azonban gyakran lehet találkozni negatív tapasztalatokkal is. Az általunk megkérdezettek 54\%-a panaszkodott amiatt (föleg a Németországban élő magyarok), hogy a külföldi lakóhelyén élő magyarok között gyenge az összefogás, nem segítik eléggé egymást a munkavállalás kezdetén, hiányoznak a magyar közösségek. A legösszetartóbb magyar diaszpórákkal Bécsben és Londonban találkoztunk.

A megkérdezett magyar munkavállalóknak 10-es skálán kellett értékelniük a külföldi fizetéssel való megelégedettséget. Kétségkívül pozitívan értékelték helyzetüket, a kint élők több mint 50\%-a nagyon vagy teljes mértékben elégedett fizetésével, sőt 5 alatti (tehát közepes vagy alacsony fokú) megelégedettséget csupán 13\%-uk jelölt. Nagyobb szórást és elégedetlenséget mutatnak az előrejutás lehetőségeire adott válaszok: harmaduk teljes megelégedettségről számolt be, viszont a szükös karrierlehetőségekről, a társadalmi ranglétrán felfelé mozdulás akadályokba ütközéséről a kint élők 37\%-ának semleges vagy negatív a véleménye.

Magyar szempontból kedvezőtlen adat, hogy a megkérdezett külföldi magyarok döntő hányada (77\%-a) nem tervezi a hazaköltözést, sőt harmaduk a közeljövőben családját is szeretné kiköltöztetni. A hazaköltözést célként kitűző, tehát a külföldi létet (ideiglenes) anyagi, egzisztenciális megerősödés okán választó emigráns magyarok 30\%-a egy éven belül, 26\%-a pedig 2 éven belül tervezi a hazaköltözést. Fő okként a családalapítást, a hazai környezetben történő gyermeknevelést, a vállalatalapítást és/vagy annak további fejlesztését, a biztos anyagi alapokon nyugvó egzisztenciát, a hitelek törlesztése után családi ház építését, valamint a hazaszeretetet említették. Még szociodemográfiai szempontból sem egyértelműen kedvezőtlen a rövidebb időre történő elvándorlás, mivel növekednek a hazautalások, a külföldi szaktudást a hazatérők később itthon kamatoztathatják, bátrabb, profibb és széles látókörü vállalkozókká válhatnak. A mérleg másik serpenyőjében a ciklikus migráció negatív hatásai találhatók: a másodlagos polgárok „termelése”, a családi integráció, kohézió gátlása, a kulturális súrlódások erősödése és a végleges visszatelepedés esélyének csökkenése.

A külföldi munkavállalás egyik fontos magyarázó tényezője a Magyarországon maradt/hagyott családtagok folyamatos anyagi támogatása. A KSH (2017) szerint a 2010 óta dinamikusan növekvő kivándorlásnak köszönhetően drámaian növekedtek a hazautalások: 920 milliárd Ft-ot tettek ki 2015-ben, amely az ország éves GDP-jének 3\%-a. A hazautalások 2012 és 2015 között 236 milliárd forinttal növekedtek, azóta a növekedés dinamikája valamelyest visszaesett a Világbank adatai szerint (data.worldbank.org 2017), azonban a hazai elemzők hosszabb távra is növekedést jeleznek (Hornyák 2016). A 920 milli- 
árd forintos hazautalás azt jelenti, hogy feltételezve, hogy 300-400 ezren rendszeresen küldenek pénzt, átlagosan 200-250 ezer forintot tesznek félre havonta a külföldön dolgozó magyarok. A jövőbeni esetleges visszaesésnek két oka lehet: a kivándorlás üteme lassul, illetve egyre többen viszik magukkal közeli családtagjaikat (főként házastársat/élettársat és gyermekeket). Számos interjúnk egy újabb jelenséget is feltárt: a magasabb jövedelmi csoportokba tartozó, külföldön biztos egzisztenciával rendelkező magyarok - az unokák nevelése és nem utolsósorban a külhoni magasabb szintű egészségügyi és szociális ellátás miatt - már a nagyszülőket is egyre nagyobb számban költöztetik ki.

Az általunk megkérdezettek fele nem támogatja itthon maradt családtagjait (vagy azért, mert nem igénylik, vagy a saját megélhetésük anyagi biztosítása után nem marad hazautalásra szánt jövedelem). Akik támogatják az itthon maradottakat, 50-150 000 forintot tudnak havi szinten hazaküldeni. (Kutatásunkban azonban a jövedelemmel, hazautalásokkal kapcsolatos kérdésekre érthetően 50\%-nál alacsonyabb válaszolási hajlandóságot tapasztaltunk, tehát eredményeink torzíthatnak.)

A GDP-arányos hazautalások tekintetében Magyarország az egykori keleti blokk országai között vezető helyen áll, 3\%-ot meghaladó értékével. A Világbank és az OECD 2015-ös számításai szerint az Európai Unió összes bruttó nemzeti termékének 0,6\%-a származik hazautalásokból, míg a kelet- és közép-európai országok GDP-jének 2,1\%-a. A 2004 után csatlakozott államok közül csak Lettország (5\%) és Horvátország $(4,3 \%)$ előzi meg hazánkat. Meglepő, hogy a régóta és magas szintű emigrációval sújtott Románia (1,7\%) és Bulgária (3\%) esetében is kisebb a hivatalos (!) hazautalások mértéke. Léteznek szélsőséges esetek is, például Moldova, ahol jelenleg minden harmadik aktív korú külföldön keresi a kenyérre valót (a GDP 25\%-át teszik ki a hazautalások), míg Koszovó is kiugró példa a maga 16,7\%-os értékével (data.worldbank.org 2017).

\section{Szubjektív jóllét a kivándorolt magyarok körében}

A World Happiness Report komplex makromodellje a szubjektív jóllétet hat tényezővel magyarázza: az egy főre jutó GDP, az egészségben eltöltött várható élettartam, azok aránya, akik baj esetén számíthatnak valaki támogatására, a korrupció elterjedtségéről alkotott vélemény, a nagylelkűség jelenléte a társadalomban (ezt az adományozás gyakoriságával mérik) és a döntési szabadság önértékelés alapján észlelt szintje (Helliwell, Layard, Sachs 2017).

A magyarok megelégedettsége, boldogságérzete az egykori vasfüggönytől keletre fekvő országok lakosainak átlagánál is lényegesen rosszabb. Idén a 10-es skálán 5,32-es átlagával a Föld 155 országából 75. helyezést ért el Magyarország (Jordánia és Jamaica között), míg a térségbeli államok egytől egyig előnyösebb pozícióval szerepeltek: Csehország 23., Szlovákia 40., Lengyelország 46., Romá- 
nia 57., Szerbia 73. Nálunk leginkább a korrupció, a döntési szabadság és a nagylelkűség (szubjektív) tényezői terén tapasztalni deficitet. A magyar elégedettség (pontosabban elégedetlenség) szintje az 1989-es politikai fordulat óta tartósan alacsony és különösebb ingadozások nélkül lassan tovább romlott. A 3. ábra is mutatja, hogy az általunk megkérdezett külföldön élő magyarok átlagos szubjektív jóllétszintje még az itthoniak pesszimista attitűdjét is alulmúlja 4,82-es értékével. Nem meglepő tehát, hogy ők az ország elhagyása mellett döntöttek, és mind objektív (gazdasági), mind szubjektív (egyéni megelégedettségi) szempontból kedvezőbb országokban telepedtek le: a világ legboldogabb államait koncentráló Észak-Európában (Norvégiában, Dániában, Izlandon mérték a legmagasabb megelégedettséget 7,5 fölötti értékkel), Svájcban, Ausztriában, az Amerikai Egyesült Államokban, Németországban, az Egyesült Királyságban.

A magyarok kirívó elégedetlenségét többek között a rossz egészségügyi ellátás magyarázza, míg a leginkább javítani képes tényező a tanulás, főleg a felsőfokú tanulmányok, a szakismeret, a nyelvismeret és a kultúra. Általánosan fontos elégedettségnövelő tényező a társadalmi kapcsolatok minősége és mennyisége, gondolva itt a párkapcsolatokra, a rokoni és a baráti viszonyokra. Magyarországon relatíve alacsony az elégedettségnövelő társadalmi kapcsolatok intenzitása, a rokoni és baráti kapcsolatok fenntartása, a biztos megélhetés megteremtése - nem önértékük (kapcsolati tőkeértékük) miatt - javítják a szubjektív jóllétet. A munkanélküliség, valamint a végzettségnek nem megfele-

3. ábra: A külföldön élő magyarok megelégedettsége Magyarországon és külföldön Satisfaction of Hungarian emigrants in Hungary and abroad

30

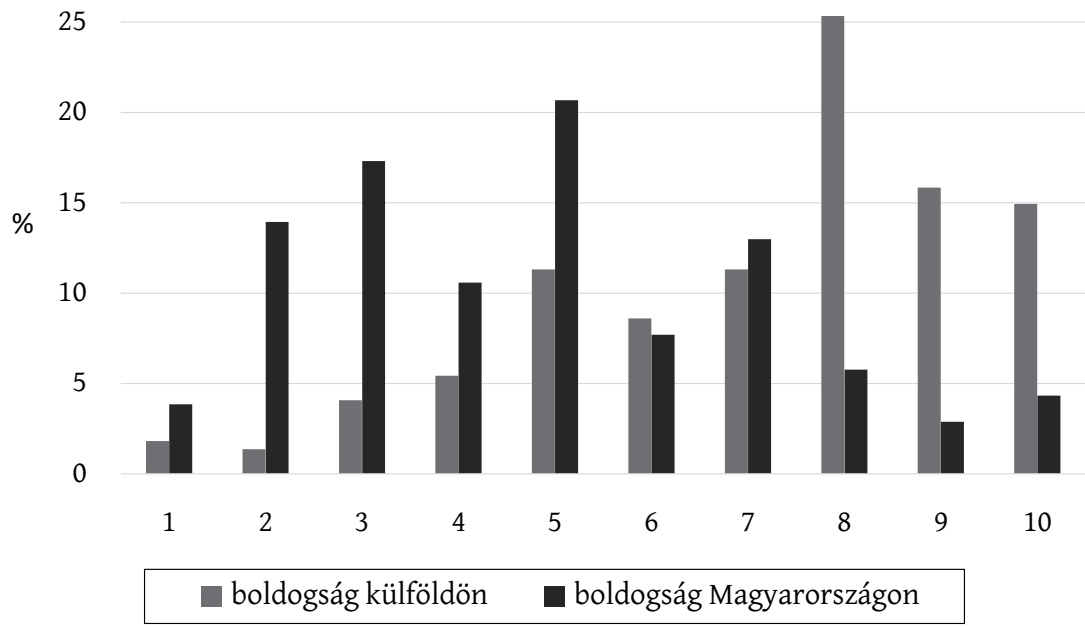

1: legkevésbé elégedett, 10: leginkább elégedett.

Adatok forrása: online kérdöiv a külföldön élő magyarok körében (n=245). 
4. ábra: A külföldi munkavállalásra sarkalló taszító és vonzó tényezők Push and pull factors promoting Hungarians' emigration
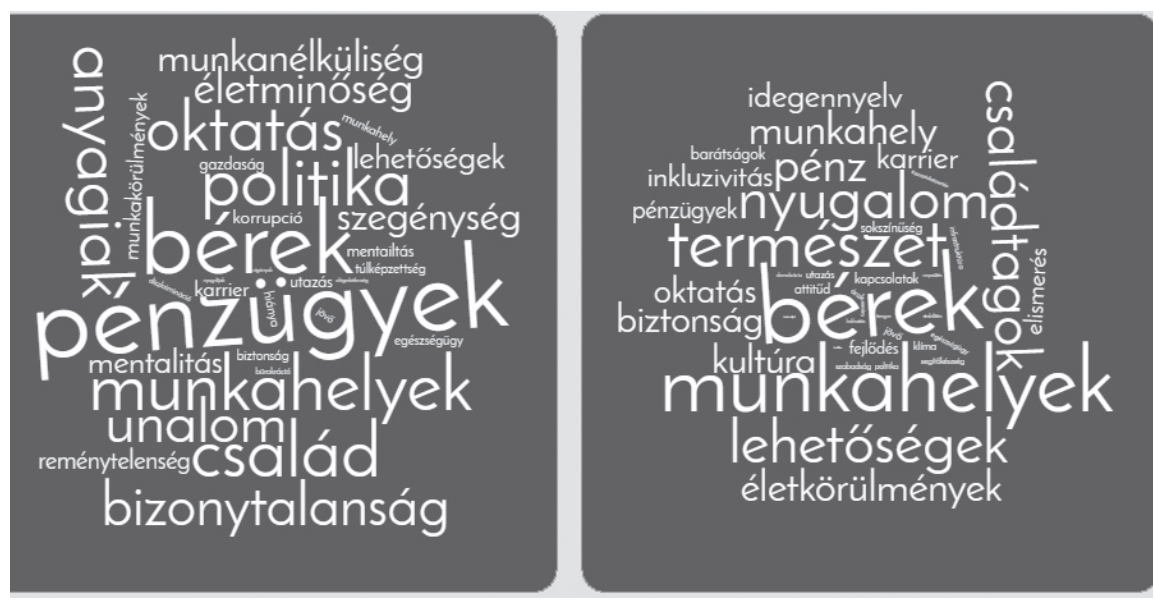

Adatok forrása: online kérdőiv a külföldön élő magyarok körében (n=245).

lő munka is rontja a megelégedettséget, sőt ez a hatás gyorsan továbbterjed a családtagokra is - a jövővel kapcsolatos anyagi és egzisztenciális bizonytalanságérzet növekedése okán (Molnár, Kapitány 2006; Sági 2006; Stutzer, Frey 2006). Ezt főként a lakhatás és a felhalmozás biztonságának veszélybe kerülése indokolja. Érdekes jelenség a vállalkozók átlagosnál nagyobb elégedettsége, amely mögött talán az eltitkolt jövedelem miatt kialakult pénzügyi és egzisztenciális biztonság áll.

Kutatásunk alátámasztja, hogy a külföldön élő magyarok elégedetlenségét magyarázó okok tárháza kimeríthetetlen. Az emigráció első számú indokai természetesen gazdasági-pénzügyi jellegüek, ezen kívül a méltó munkakörülményeket, az előrelépés lehetőségét hiányolják (4. ábra). A bizonytalanság, a depriváció, a reménytelenség szintén taszító faktor, amely a növekvő mértékben polarizálódó társadalom terméke, különösen a társadalom alsó és középső státuszcsoportjaiba tartozókat sújtva. Az évtizedek alatt egyre szélesebb társadalmi törésvonalakat mélyítő politika, a súlyosbodó korrupció, a panasztársadalom, valamint a polgári öntudat hiánya mind-mind indoka a kivándorlásnak.

A külföldi ideiglenes vagy végleges letelepedés elsősorban a magasabb bérek, a karrierlehetőség, a sokszínủbb munkaerőpiac miatt vonzó (4. ábra). Emellett az itthon maradt családtagok biztos támogatása, az idegennyelv-tanulás, a multikulturális környezet pozitív légköre (tolerancia, befogadás), a külföldi kapcsolati háló erősítése, bővítése, az elismerés iránti vágy, valamint a természeti környezet minősége képezik az emigráció motivációit.

A realitások talajától azonban gyakran elrugaszkodva az emigráció mellett döntők hajlamosak a mobilitás előnyeinek felülértékelésére, sokszor túlzott mértékü kitörési lehetőségként tekintenek a külföldi munkavállalásra, ami ma 
már a felnövekvő generációk életstratégiáját is meghatározza és befolyásolja a továbbtanulási szándékot. A kivándorlást sokan önmagában társadalmi mobilitásként értelmezik.

\section{Összefoglalás}

A magyarok kivándorlása, külföldön folytatott tanulása, munkavállalása egyre inkább életstratégiává válik nemtől, kortól, társadalmi osztálytól, iskolai végzettségtől, származástól, lakhelytől, szocializációs háttértől, egyéni kulturális jellemzőktől függetlenül. A magyarok emigrációs hajlandósága 2010-ig elmaradt a posztszocialista átmeneti országok társadalmait már a 2000-es évek eleje óta sújtó nagyütemű kivándorlástól. Ezzel együtt az Európai Unió munkaerőpiacának megnyitása, kiegészülve a családok ezreinek eladósodását okozó világgazdasági recesszióval, 1989 után Magyarországról is elindította és felgyorsította a külföldre vándorlást. A magyar emigráció célországainak sorrendjét Németország és az Egyesült Királyság vezeti, a harmadik helyen Ausztria áll. A három országban együttesen közel 300 ezer magyar dolgozik, tanul vagy él együtt emigráns családtaggal. Észak-Európa, a Benelux államok, Svájc, Olaszország és Spanyolország, sőt Lengyelország és Szlovákia is egyre jelentősebb mobilitási célponttá válik. Jelenleg a külföldön élő magyarok száma becslések szerint 350 és 600 ezer fő közé tehető, a kiköltözés dinamikája 2010-től 2014-ig növekedett, azóta magas szinten stagnálást, kismértékű lassulást lehet tapasztalni.

A migráció jövőbeli mintázatai kiszámíthatatlanok, ugyanis a makrogazdasági környezet, az intézményhálózat, a szociális és egészségügyi ellátórendszer, az oktatás színvonala, a politikai klíma alapvető befolyást gyakorol az individuális és családi döntésekre. Tény, hogy míg két évtizede kalandvágynak számított a migrációs lét, jelenleg általánosan elfogadott életstratégia, amely lehet végleges és ideiglenes, esetleg időnként megismétlődhet. Egyre összetettebb külföldi kapcsolati hálók alakulnak ki, egyre szélesebben tapossák ki a migráció szimbolikus ösvényeit. Gazdasági téren a GDP 3\%-át kitevő hazautalások jelentősen javítják az otthon maradottak életszínvonalát, a gazdasági-társadalmi felzárkózáshoz azonban nem elégségesek.

A kivándorló magyarok kétharmada nem tervezi a hazaköltözést, sőt családtagjaikat is egyre gyakrabban költöztetik magukhoz. A migrációt tudatosan ideiglenes állapotnak felfogó, anyagi és egzisztenciális megerősödést biztosító lehetőségként tekintő magyar állampolgárok - az előző csoporttal szemben - a családi kötelékek, a magyarországi vállalkozás indítása, a hazai karrierlehetőségek és a hazaszeretet, a lokálpatriotizmus miatt rövidebb-hosszabb idő elteltével visszaköltöznek az országba. A remigráció a kvalifikáltabbak irányában szelektív, azon túlképzett magyarok, akik nem jutnak végzettséghez megfelelő munkához, hajlamosabbak a hazatérésre (és az újabb szerencsepróbálásra). 
Mindehhez hozzá kell tenni, hogy a vizsgálatunkban megkérdezettek lényegesen nagyobb csoportja (77\%-a) nem tervezi a hazaköltözést.

A migráció mögött megszámlálhatatlan vonzó és taszító tényező áll. A kivándorlásra ösztönző okok között legfontosabb a pénzügyi instabilitás, az alacsony bérek, a gazdasági recesszió, az oktatás alacsony színvonala, a közösségeket, családokat, barátokat egymástól eltávolító, mételyező politika hatása, a szegénység, a munkanélküliség, a reményvesztettlét-érzés, valamint a közeli és távoli jövővel kapcsolatos teljes bizonytalanság. Ezzel ellentétben a célországok a négy-hatszoros fizetés, a biztos munkahely, a karrierlehetőségek, a megtakarítások lehetősége, az itthon maradt (hagyott) családok anyagi támogatása, a jobb életkörülmények, a kulturális sokszínűség, a befogadó társadalmi légkör, a multikulturális környezetben történő szocializálódás előnyei, az idegen nyelvtudás megszerezhetősége, az oktatás magas színvonala, a minőségi természeti környezet és a kiszámítható jövő miatt válnak vonzó letelepedési és jövőépítési helyszínekké.

\section{Köszönetnyilvánítás}

A kutatás az OTKA 109449. számú, Legújabb trendek a magyarországi kivándorlásban című, 2013 és 2017 között megvalósuló kutatási projekt támogatásával készült.

\section{Irodalom}

Béni, A. (2016): This is what Hungarians do for living in the U.K. DailyNews Hungary, július 30. https:// dailynewshungary.com/this-is-what-hungarians-do-for-a-living-in-the-u-k/(Letöltés: 2017.április 21.)

Blaskó Zs., Fazekas K. (szerk.) (2016): Munkaerőpiaci tükör 2015. MTA KRTK Közgazdaság-tudományi Intézet, Budapest

Blaskó Zs., Gödri I. (2014): Kivándorlás Magyarországról: szelekció és célország-választás az „új migránsok" körében. Demográfia, 4., 271-307.

Blaskó Zs., Ligeti A. S., Sik E. (2014): Magyarok külföldön - Mennyien? Kik? Hol? In: Kolosi T., Tóth I. Gy. (szerk.): Társadalmi riport 2014. TÂRKI, Budapest, 351-372.

Bundesagentur für Arbeit (2017): Auswirkungen der Migration auf den deutschen Arbeitsmarkt. Bundesagentur für Arbeit, Nürnberg (Berichte: Arbeitsmarkt kompakt)

Destatis (2017): Ausländische Bevölkerung nach ausgewählten Staatsangehörigkeiten. https://www. destatis.de/DE/ZahlenFakten/GesellschaftStaat/Bevoelkerung/MigrationIntegration/ AuslaendischeBevolkerung/Tabellen/StaatsangehoerigkeitJahre.html (Letöltés: 2017.április 3.)

European Commission (2014): EU Employment and Social Situation. Quarterly Review with supplement on "Recent trend in the geographical mobility of workers in the EU" http://ec.europa.eu/ social/main.jsp?langId=en\&catId=89\&newsId=2087\&furtherNews=yes (Letöltés: 2017. május 2.)

Eurostat (2017): Wages and labour costs. http://ec.europa.eu/eurostat/statistics-explained/index.php/ Wages_and_labour_costs (Letöltés: 2017. április 24.)

Farkas M. (2015): Többszörösére nőtt az ingázók száma. Magyar Nemzet, június 10. https://mno.hu/ belfold/tobbszorosere-nott-az-ingazok-szama-1290075 (Letöltés: 2017. május 3.) 
Fazekas K., Varga J. (szerk.) (2015): Munkaerőpiaci tükör 2014. MTA KRTK Közgazdaság-tudományi Intézet, Budapest

Gödri, I. (2015): International migration. In: Monostori, J., Orti, P., Spéder, Zs. (eds.): Demographic Portrait of Hungary 2015. Hungarian Demographic Research Institute, Budapest, 185-209.

Hárs Á. (2008): Csatlakozás és csalatkozás - a magyar munkaerőpiac és a migráció. In: Kolosi T., Tóth I. Gy. (szerk.): Társadalmi riport 2008. TÁRKI, Budapest, 108-130.

Hárs Á. (2012): A munkaerő migrációja Magyarországon a kilencvenes és a kétezres években. Bevándorlás és elvándorlás a munkaerö-felmérés alapján. MTA KTI, Budapest (TÁMOP-2.3.2-09/1 Műhelytanulmányok; T/15.)

Hárs Á. (2016): Elvándorlás és bevándorlás Magyarországon a rendszerváltás után - nemzetközi összehasonlításban. In: Blaskó Zs., Fazekas K. (szerk.): Munkaerőpiaci tükör 2016. MTA KRTK Közgazdaság-tudományi Intézet, Budapest, 39-53.

Hárs Á., Simon D. (2016): Munkaerő-migráció, ingázás, kivándorlás. In: Blaskó Zs., Fazekas K. (szerk.): Munkaerőpiaci tükör 2015. MTA KRTK Közgazdaság-tudományi Intézet, Budapest, 72-85.

Helliwell, J. J., Layard, R., Sachs, J. (eds.) (2017): World happiness report. Sustainable Development Solutions Network, New York http://worldhappiness.report/wp-content/uploads/sites/2/2017/ 03/HR17.pdf (Letöltés: 2017. május 5.)

Heti Világgazdaság (2014): Németországban él, de gyerekeit itthon hagyta? Kap 400 eurót! http://hvg.hu/gazdasag/20140916_llyen_csaladi_potlekrol_se_hallott_meg (Letöltés: 2017. május 7.)

Hornyák J. (2016): Több kivándorló utal haza, de kevesebbet? Világgazdaság, augusztus 19. https://www.vg.hu/ gazdasag/tobb-kivandorlo-utal-haza-de-kevesebbet-474297/ (Letöltés: 2017. november 2.)

Horváth Á. (2016): Visszatérő kivándorlók. In: Blaskó Zs., Fazekas K. (szerk.): Munkaerőpiaci tükör 2016. MTA KRTK Közgazdaság-tudományi Intézet, Budapest, 106-115.

Kolosi T., Tóth I. Gy. (szerk.) (2014): Társadalmi riport 2014. Tárki, Budapest

Kolosi T., Tóth I. Gy. (szerk.) (2016): Társadalmi riport 2016. Tárki, Budapest

KSH (2014): SEEMIG Managing migration in South East Europe - Helyzetkép a magyarországi elvándorlásról 2014. Budapest

KSH (2017): Nemzeti számlák, GDP. https://www.ksh.hu/nemzeti_szamlak_gdp (Letöltés: 2017. április 25.)

Kurekova, L. (2011): Theories of migration: Conceptual review and empirical testing in the context of the EU East-West flows. Interdisciplinary conference on migration c. konferencia-előadás. Economic change, social challenge, University College, London, 2011. április 6-9.

Lados, G., Hegedűs, G. (2016): Returning home: An evaluation of Hungarian return migration. Hungarian Geographical Bulletin, 4., 321-330. http://doi.org/cf22

Lakatos K. (2015): Külföldön dolgozó magyarok, Magyarországon dolgozó külföldiek. Statisztikai Szemle, 2., 93-112.

Martin, R., Radu, D. (2012): Return migration: The experience of Eastern Europe. International Migration, 6., 109-128. http://doi.org/f4c6xk

Massey, D. S., Arango, J., Hugo, G., Kouaouci, A., Pellegrino, A., Taylor, J. E. (1993): Theories of international migration: A review and appraisal. Population and Development Review, 3., 431-466. http://doi.org/fpbvf4

Molnár Gy., Kapitány Zs. (2006): Mobilitás, bizonytalanság és szubjektív jól-lét Magyarországon. Közgazdasági Szemle, október, 845-872.

Moreh, C. (2014): Magyar bevándorlók az Egyesült Királyságban: demográfiai, földrajzi és szociológiai körkép. Demográfia, 4., 309-343.

Piesse, M. (2014): Factors influencing migration and population movements. Future Directions International, Dalkeith (Strategic Analysis Paper)

Rohr A. (2012): Kivándorlási, külföldi munkavállalási tervek a PTE hallgatóinak körében. Acta Sociologica, 5., 181-190.

Sági M. (2006): A lakossági elégedettség alakulása. In: Szivós P., Tóth I. Gy. (szerk.): Feketén, fehéren. TÁRKI, Budapest, 149-162. (TÁRKI Monitor Jelentések, 2005)

Siskáné Szilasi B., Halász L., Gál-Szabó L. (2017): A magyar fiatalok erősödő kivándorlási szándékának kiváltó okai és jellemzői. Tér és Társadalom, 4., 131-147. http://doi.org/10.17649/TET.31.4.2885

Stutzer, A., Frey, B. S. (2006): What happiness research can tell us about self-control problems and utility misprediction. Institute for Empirical Research in Economics University of Zurich, Zurich (IZA Discussion Paper; 1952) 
Szeitl B. (2015): Helyzetkép a mai magyarországi migrációs folyamatokról. Forrás, 7., 214-224.

UN (2017): World Population Prospects 2017. United Nations, DESA / Population Division. https://esa. un.org/unpd/wpp/ (Letöltés: 2017. május 5.)

Vargas-Silva, C. (2017): EU migration to and from the UK. http://www.migrationobservatory.ox.ac.uk/ resources/briefings/eu-migration-to-and-from-the-uk/ (Letöltés: 2017. április 29.)

https://data.worldbank.org/indicator/BX.TRF.PWKR.DT.GD.ZS (Letöltés: 2017. május 2.)

http://hungarianspectrum.org/2014/06/08/hungarian-immigrants-in-london-and-environs/ (Letöltés: 2017. május 5.) 